\begin{tabular}{|c|c|c|c|c|}
\hline \multirow[t]{8}{*}{ 臨床 } & \multicolumn{4}{|c|}{$\begin{array}{c}\text { 髄膜癌腫症と横断性脊髄障害を呈した } \\
\text { 腫瘤形成性形質細胞腫の } 1 \text { 剖検例 }\end{array}$} \\
\hline & \multicolumn{4}{|c|}{ 奈良県立医科大学神経内科 } \\
\hline & 舟川 & 格〉 & 堀川 博誠 & \multirow{2}{*}{$\begin{array}{l}\text { 本田＼cjkstart午 } \\
\text { 小長谷正明 }\end{array}$} \\
\hline & 寺本 & 純 & 小長谷陽子 & \\
\hline & 榊原 & 敏正 & 真野 行生 & 高柳 哲也 \\
\hline & \multicolumn{4}{|c|}{ 神戸大学医療技街短期大学 } \\
\hline & \multicolumn{4}{|c|}{ 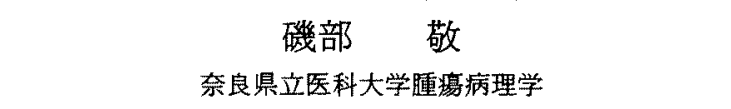 } \\
\hline & & & 博司高橋 & 精一 \\
\hline
\end{tabular}

\title{
TUMOR FORMING PLASMACYTOMA WITH MENINGEAL INFILTRATION AND TRANSVERSE MYELOPATHY: REPORT OF A CASE
}

Itaru FunaKaWA, MD, Hirosei HORIKAWA, MD, Hitoshi HONDA, MD,

Jun Teramoto, MD, Yoko Konagaya, MD, Masaaki Konagaya, MD,

Toshimasa SAKakibara, MD, Yukio Mano, MD and Tetsuya TAKaYAnagi, MD

Department of Neurology, Nara Medical University

Takashi IsOBE, MD

The Allied Medical Science, Kobe University

Hiroshi Maruyama, MD and Seiichi Takahashi, MD

Department of Oncological Pathology, Nara Medical University

\begin{abstract}
概要 29才, 男性. 27才の時に肩甲部痛, 背部・腰部痛とともに舌の右への偏位に気付いた。 その後, 胸部絞扼感, 乾性咳濑、下肢脱力感が出現したため, 入院. 胸部X線写真で多量の胸 水と左肺に円形陰影を認めた. 胸部CTで左後部胸腔内の腫瘤と判明した. 胸水細胞診にて異型 形質細胞を証明した。血清M成分は認めず血中IgA, IgG, IgM, IgE, IgDは全て低值であったが, 尿中にはx型のBence Jones蛋白を認めた。髄液蛋白の著明增加む認めた。舌は右へ偏位し楾維 束彎粨を認めた。 入院後数日にしてTh5以下の横断性春䯣障害を来した. 入院 2 力月後には項部

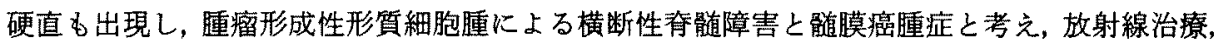
薬物治療を行なつたが，全経過14カ月で死亡した。剖検では肉眼的には脳硬膜・軟膜には肥厚 や混濁を認めず, 頭蓋底部にも異常を認めなかつた。先髄はTh5のレベルで腫瘤により王迫され

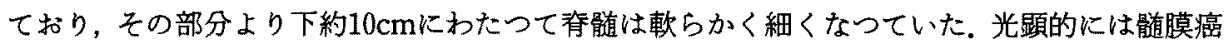

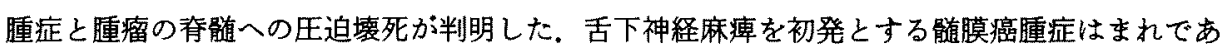

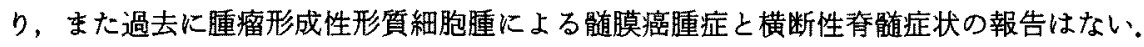

[昭和59年 8 月 23 日受稿〕

本論文の要旨第 109 回日本内科学会近畿地方会(昭和 57 年 12 月 4 日), 第111回日本内科学会近畿地方会（昭和58年 9 月17日）に拉いて発表した。
はじめに

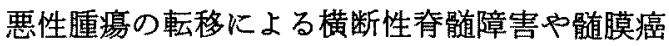
腫症は今までにも多くの報告がある，ところが舌 下神経麻疸を初発症状とする髄膜癌腫症の報告は 極めて少なく，形質細胞腫による㵦膜癌腫症の報 
告もまれである，我々は歩行困難と構語障害を主 訴とした腫瘤形成性形質細胞腫による髄膜癌腫症 と横断性资髄障害の症例を経験したので，文献的 考察を加えて報告する。

\section{症例}

患者：29才，男性，会社員（ID-0433659）.

主訴：歩行困難, 構語障害.

家族歴：胃癌（母方の祖父）。

既往歴：帯状へルペス（26才）。

現病歴：昭和56年12月，両側の肩甲部痛と運 動後の背部痛扎よび腰痛が出現した．昭和57年 1 月15日に舌が動きにくく，舌の右への偏位に気付 いた。半月後より体動時の胸部絞扼感と乾性咳嗽 が出現. その後両下肢の感覚鈍麻々脱力感に気付 き, 昭和57年 2 月 9 日奈良県立医科大学神経内科 に入院した.

入院時現症：栄養状態は不良, 体温は $37.0^{\circ} \mathrm{C}$
血王 $100 / 40 \mathrm{mmHg}$ ，脈拍 124 回/分，整．左肺で呼 吸音が低下，心雑音はなく，腹部には異常所見を 認めず，リンパ節は触知しなかつた。

神経学的所見：見当識は良好であつた。舌は 萎縮し，線維束彎縮と右への偏位を認めた。四肢 の筋緊張は正常であつた，筋力は左下肢で中等度 の低下を認めた。独歩は可能であり，つま先歩き， 踵歩きも行なえたが，跳躍は不可能であつた。深 部反射は正常ないし軽度低下し，病的反射は陰性 であつた，左下肢の表在知覚の低下を認めた。

検查所見：表 1 亿血液, 尿, 髄液, 骨髄穿刺 の検查結果を示す，末血所見は正球性正色素性貞 血で異常細胞は認めなかつた，血沈は 1 時間值 22 $\mathrm{mm}$ と軽度え進. 総コレステロールは $86 \mathrm{mg} / \mathrm{dl}$, 総 蛋白は $5.3 \mathrm{~g} / \mathrm{dl}$ と低值で, 血清IgA, IgG, IgM, IgE,

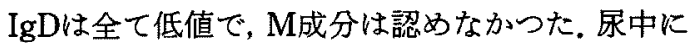
は $\beta$ - $\boldsymbol{\gamma}$ 位にBence Jones蛋白を認めた. 腰椎穿刺に

表 1，入院時検查成樍

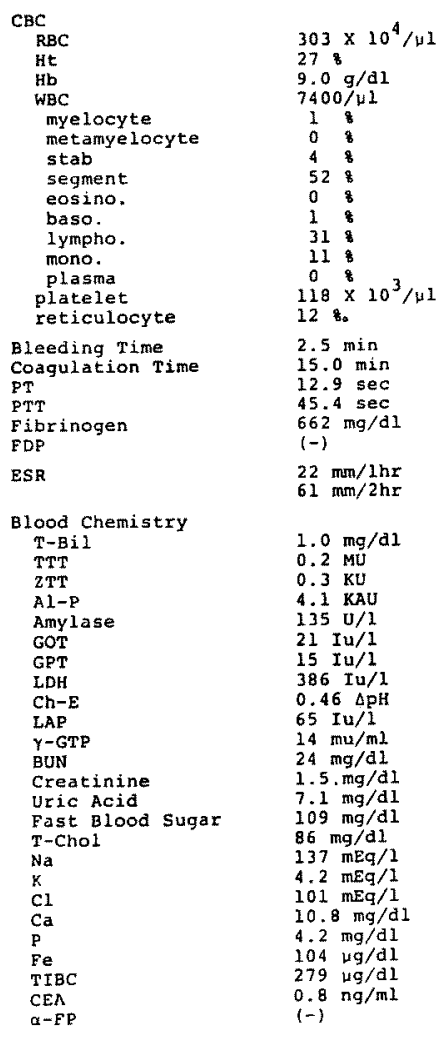

昭和 60 年 9 月 10 日

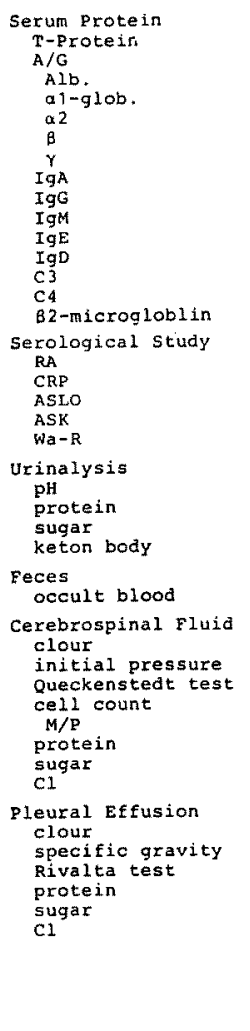

Bone Marrow Picture myelobl. myelo. myelo. meta. segment eosino. baso. lympho. mono. $\begin{array}{lll}25+\mathrm{IU} / \mathrm{ml} & \text { mono. } & 7.6 \\ \text { not detected } & \text { reticulo. } & 2.0 \\ 74.3 \mathrm{mg} / \mathrm{dl} & \text { erythro. } & 2.4 \\ & & 7.6\end{array}$ $\begin{array}{lll}\text { not detected } & \text { reticulo. } & 2.0 \\ 74.3 \mathrm{mg} / \mathrm{dl} & \text { erythro. } & 2.4 \\ & & \text { plasma }\end{array}$ $\begin{array}{lll}\text { not detected } & \text { reticulo. } & 2.0 \\ 74.3 \mathrm{mg} / \mathrm{dl} & \text { erythro. } & 2.4 \\ 29.3 \mathrm{mg} / \mathrm{dl} & \text { plasma } & 7.6\end{array}$

not counted 0 0.4 7.6 40.4 0 32.0 $\begin{array}{lll}25+\text { IU/ml } & \text { mono. } & 7.6 \\ \text { not detected } & \text { reticulo. } & 2.0 \\ 74.3 \mathrm{mg} / \mathrm{dal} & \text { erythro. } & 2.4 \\ 29.3 \mathrm{mg} / \mathrm{s} & \text { plasma } & 7.6\end{array}$ $29.3 \mathrm{mg} / \mathrm{d}$ (-)

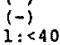
$1:<40$
$(-)$
$(-)$

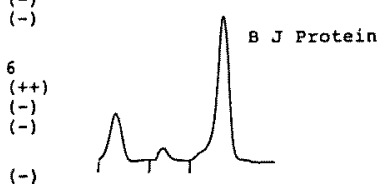

(-)

Xanthochromic 225 minh $_{2} \mathrm{O}$

norma

$60 / 3$
$59 / 1$

$59 / 1$
$1950 \mathrm{mg} / \mathrm{al}$

$60.6 \mathrm{mg} / \mathrm{dl}$

$123 \mathrm{mEq} / \mathrm{l}$

Xanthochromic

1.024

$3.09 \mathrm{~g} / \mathrm{dl}$

$132.2 \mathrm{mg} / \mathrm{dl}$

$107 \mathrm{mEq} / \mathrm{l}$ 
て脳脊髄液は初圧が $225 \mathrm{mmH}_{2} \mathrm{O} て ゙ Q u e c k e n s t e d t$ 試験は正常であつた。外観はキサントクロミーで 蛋白は $1950 \mathrm{mg} / \mathrm{dl}$ と著増. 細胞数は60/3で, 万ち単 核球が59/3で，異常細胞は認めなかつた．昭和57 年 3 月 22 日に行なつた腰椎穿刺では初圧 $180 \mathrm{~mm}$ $\mathrm{H}_{2} \mathrm{O}$ で $4.5 \mathrm{ml}$ 採取後の終圧は $75 \mathrm{mmH}_{2} \mathrm{O}$ であつた。 Queckenstedt試験では圧の上昇を認めなかつた。 このときの蛋白は $1760 \mathrm{mg} / \mathrm{dl}$ であつた。 3 月30日 にはからうじて約 $2 \mathrm{ml}$ 脳脊䯣液が得られたが, 䯣液の $\mathrm{IgA}$ は $5.9 \mathrm{mg} / \mathrm{dl}, \mathrm{IgG} 121.8 \mathrm{mg} / \mathrm{dl}$ で $\mathrm{IgG}$ が著明に増加していた。 また特異抗血清により Bence Jones蛋白の存在が疑われた。昭和57年 2 月17日に行なつた胸骨骨髄穿刺ではhypoerythroid marrowといら所見以外特記すべき事項はな かつた. 形質細胞は $7.6 \%$ と比率が高いが異型細胞 は認められなかつた。骨䯣クロット標本は作製し なかつた. 再検した胸骨骨䯣穿刺はdry tapであつ た。な饾蓋単純レントゲン写真で骨破壊像は認 めなかつた。 入院時の胸部レントゲン写真では多 量の胸水と左第一弓の少し上に円形の異常陰影を

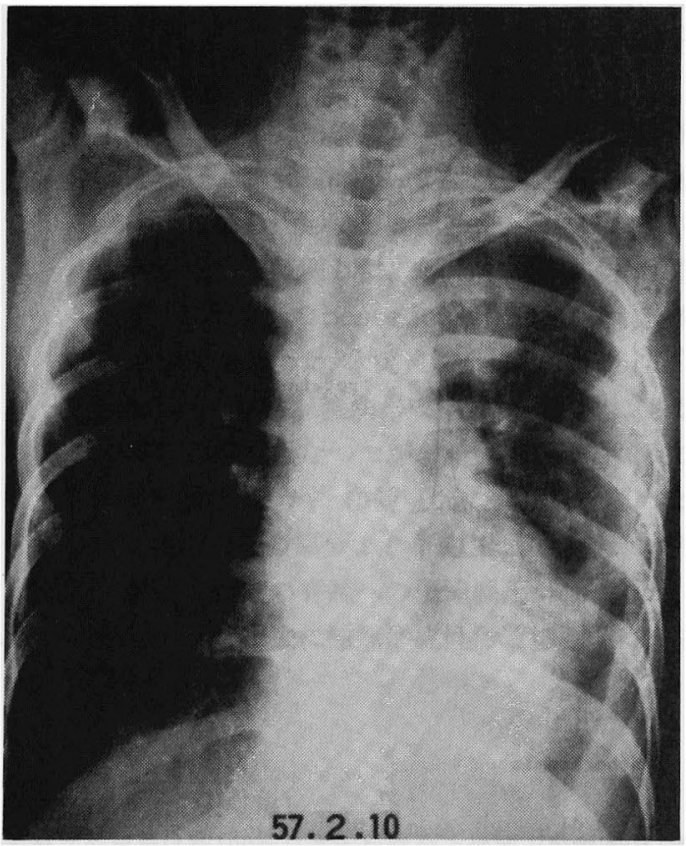

図 1. 胸部レントゲン写真. 左第 1 弓の上に円形の陰 影を認める。
認めた（図 1)。この異常陰影は全身CTスキャン で左後部胸腔内の球形の腫瘤と判明した。ささらに 胸水細胞診にて，核構造物が粗䊁で一部は核分裂 像も見られる異型形質細胞を認め(図 2 )，螢光抗 体法でこの細胞質は抗火に対して陽性を示した。 胸水蛋白は $3.1 \mathrm{~g} / \mathrm{dl}$, リバルタ反応が陽性で浸出液 であつた，昭和57年 4 月21日の胸水中にBence Jones蛋白が証明された.これは後日 $\boldsymbol{x}$ 型であるこ とが判明した。

入院後経過（図 3 ）：入院後数日でTh5以下の 横断性脊髄障害に陥つた。すなわちこのレベル以 下の筋力消失, 全知覚消失, 深部反射の消失, 筋 緊張の低下．両便失禁が次々に出現した。ささらに 発汗状態に明瞭な境界があり，このレベルより上 位の皮膚は湿潤で，下位の皮膚は乾燥していた。 この横断性脊䯣障害は後述する治療には反応しな かつた. 舌の偏位の方向は一定せず昭和57年 1 月, 3 月下旬, 4 月中旬, 5 月から 8 月下旬をでは右 に偏位を示した(図 4 )。 2 月， 3 月中旬，8 月下 旬は舌に偏位を生じなくなり，その間 2 月に一度 左に偏位を示した．挺舌は入院後しだいに困難と なり， 2 月下旬には歯列を越えることができなく なつた。 3 月上旬には線維束攣縮，萎縮が著明と なり舌の動きは著しく制限され，挺舌を行な拈う としてもかすかに舌が動くのみの状態となつた. 3 月下旬には萎縮も非常に軽度となつた。 4 月に なると少し増悪してきたが，5月以後徐々に萎縮

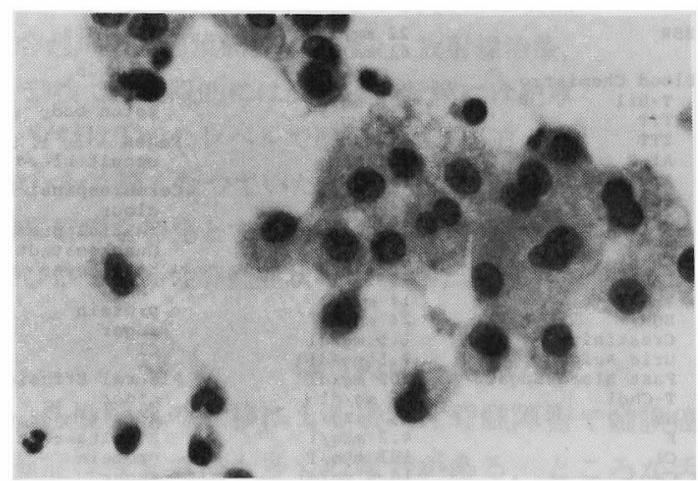

図 2.胸水細胞診(パパニコロ染色, $\times 400)$ ，異型形質 細胞を認める，核分裂像も見られる。 

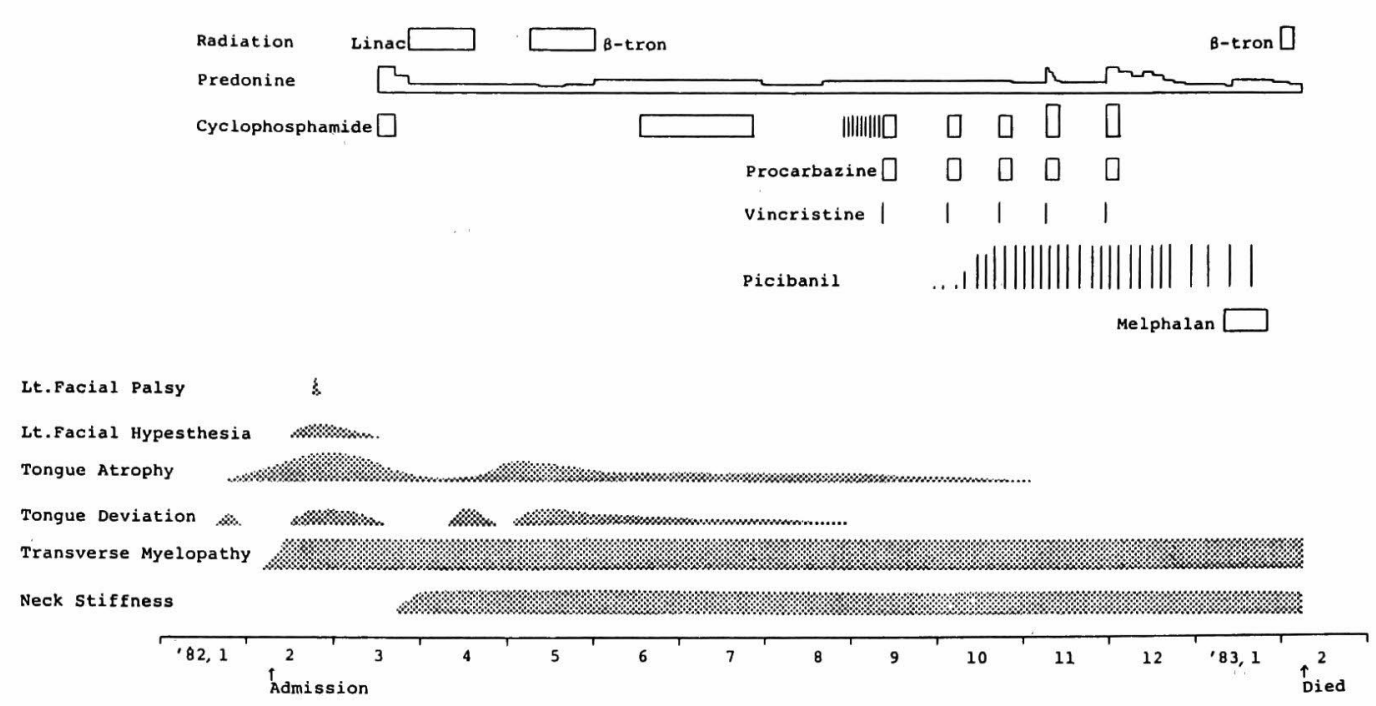

図 3.臨床経過㧍よび治療

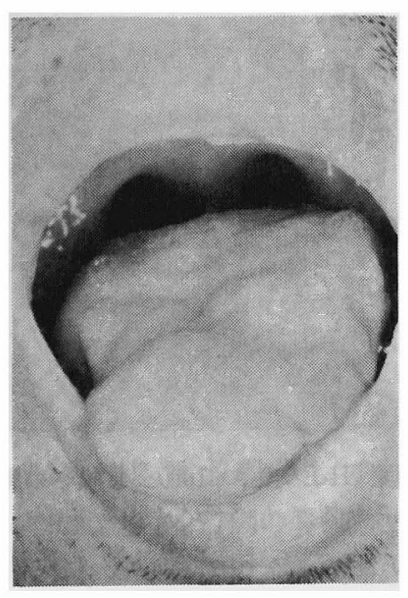

図 4.舌は萎縮し, 右に偏位を示している.(昭和 57 年 5 月)

は改善し，11月には萎縮・線維束攣縮は共に消失 し, 挺舌時に偏位を認めず，動きも完全に正常に 戻つている.

昭和 57 年 2 月中旬から 3 月中旬には左顔面神経 麻瘒, 2 月下旬には左顔面の知覚鈍麻が出現した. この第 V, 第VII脳神経症状は一過性であつた. 項 部硬直は入院当初には認められなかつたが，3月 23日より出現し，これは治療に反応しなかつた。 なお，経過中レントゲン写真上，右大腿骨と右肩
甲骨に打ち抜き像が出現した。

検查結果と臨床症状より「形質細胞腫がTh5レ ペルで硬膜外より瓷髄を王迫し, 一方で髄膜癌腫 症として，第V，VII, XII脳神経症状を呈した」も のと考光，放射線治療と薬物治療を行なつた．放 射線治療として脳底部に2000rad, 左肺円形陰影 とTh5を中心とする胸髄に4000radのLinacを照 射した.このため入院時に認めた左肺野の異常陰 影はX線像上消失した。薬物治療としては全期間 中にステロイドを使用し，9月11日，10月 4 日， 10月19日，11月 8 日，11月28日に計 5 回VENP療 法を行なつた。すなわちvincristine $3 \mathrm{mg}$ を 1 日 間, cyclophosphamide $100 \mathrm{mg} /$ 日を 4 日間, procarbazin $150 \mathrm{mg}$ /日を 4 日間, prednisolone 30〜60mg/日を 4 日間投与した.またmelphalan 2 $\mathrm{mg} /$ 日を昭和58年 1 月13日から 1 月 25 日まで投与 した. picibanilは0.2KEから始め5.0KEまで計30 回投与した．末期には肋骨に沿う多数の腫瘤と鼠 径リンパ節転移が出現したが，2月 7 日急性呼吸 不全にて死亡した。全経過は14カ月であつた。

剖検所見： 解剖は死亡 4 時間後に行なつた。 身長 $163 \mathrm{~cm}$, 体重 $42.5 \mathrm{~kg}$, やせが著明. 右側に 1500 $\mathrm{ml}$, 左側に $1000 \mathrm{ml}$ 胸水, $200 \mathrm{ml}$ 腹水を認めた。 肺は両側軽度のらつ血所見を認めた。肉眼的に両 
側胸壁，肺門部リンパ節，右第 4 ，第 5 肋骨，右 臼径リンパ節，腸間膜，右大腿骨，左肺下部に転 移巣を認めた．脊椎周囲，先柱管内にも母指頭大 の腫瘤が多数認められた．組織学的には肝に中心 性壊死，脾に軽度の赤芽球系の䯣外造血所見を認 め，傍気管リンパ節には乾酪壊死が確認され，活 動型の結核が示唆された，骨髄脱灰標本では，骨 䯣成分は正常に保たれていたが，骨髄外からの腫 瘍細胞の浸潤が認められた。

脊髄は脊柱管内の腫瘤により压迫され，Th5以 下約 $10 \mathrm{~cm}$ にわたり，細く，軟らかく，やや褐色調 を呈し，壊死に陥つていた。硬膜と腫瘤の剥離は 容易で，硬膜に混濁や肥厚は認められなかつた。

脳重量は $1190 \mathrm{~g}$ で肉眼的には著変を認めなかつ た，大脳表面の混濁や軟硬膜に肥厚に認めなかつ

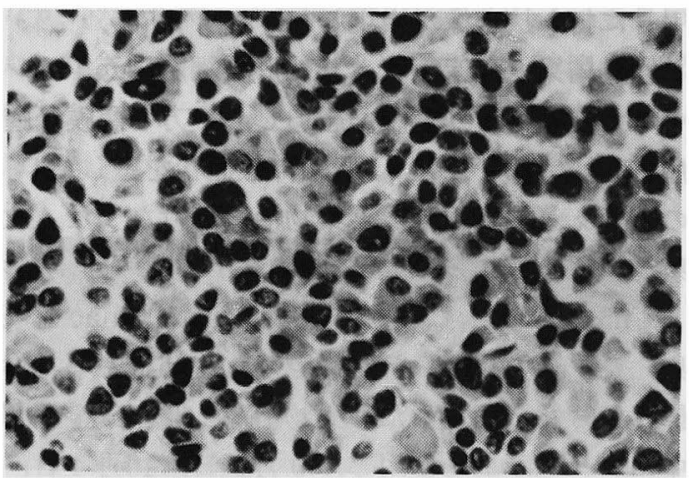

図 5 ，脊椎周囲の腫瘤 $(\mathrm{H}-\mathrm{E}$ 染色, $\times 400)$, 胸水細胞診 と同じ異型形質細胞が多数認められる.

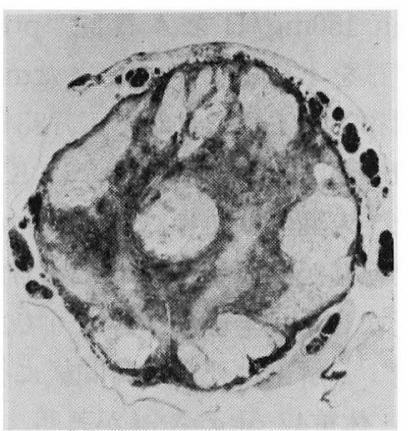

図 6. 胸䯣 (壊死部) の断面像 (K-B染色, $\times 2.5)$. 脊 髄実質はcysticな変化に樎つている.
た，頭蓋底にも癌の浸潤を思わせる所見は認めな かつた。

図 5 は脊椎周囲にあつた腫瘤の一つをへマトキ シリン エオシンン染色で見たものである，腫瘤形 成性の形質細胞腫で，腫瘍境界は膠原線維で囲ま れていた，壊死に陥つた胸䯣の横断面のKlüverBarrera染色では, 先髄実質はcysticな变化に陥つ て扣り(図 6 )， astrocyte，microgliaの浸潤が著 明であつた。また軟膜には腫瘍細胞の浸潤が認め られた。この軟膜への浸潤は大脳，脳幹部にも認 められた（図 7 ). 第12脳神経のperineuriumにも 腫瘍細胞の浸潤が認められ，髄鞴は菲薄化してい た(図 8 )。厈迫部位より上位の春䯣では後索と脊

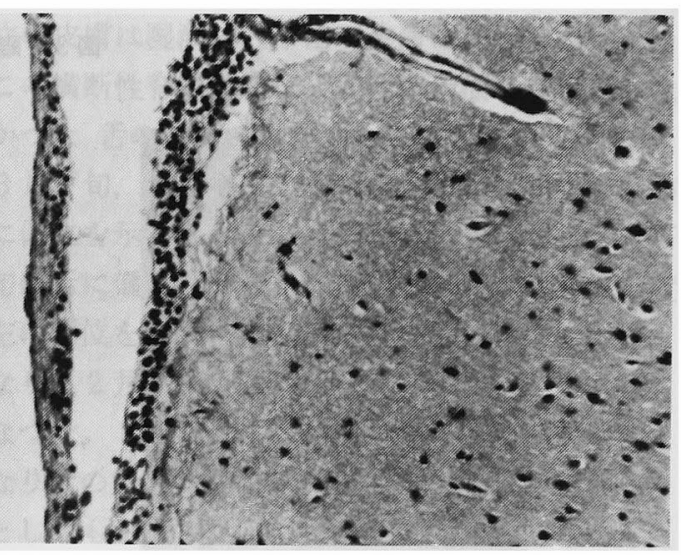

図 7 前頭葉 $(\mathrm{H} \cdot \mathrm{E}$ 染色, $\times 100)$. 軟膜への腫湯細胞の 浸潤が認められる。

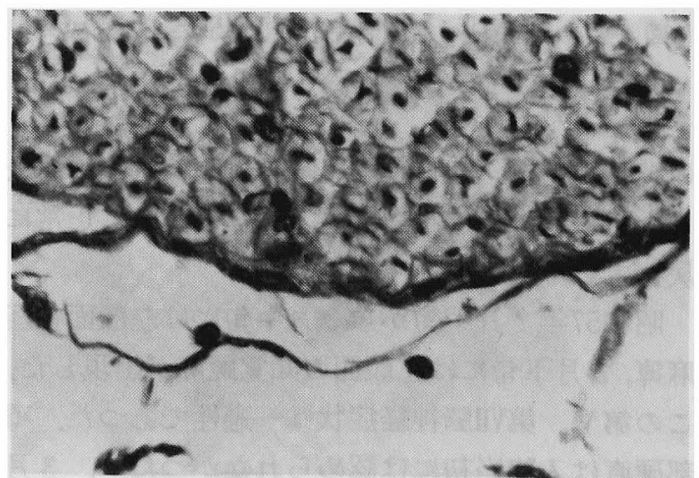

図 8 . 右舌下神経 $(\mathrm{H}-\mathrm{E}$ 染色, $\times 400)$. Perineurium の腫瘍細胞の浸潤が認められる. 
䯣小脳路が海綿状変化に陥り上行性变性を示唆し ていた。

\section{考案}

本例は歩行困難, 構語障害を主訴として来院し た29才，男性で，不可逆性の横断性资髄障害が出 現. 検查所見として，尿蛋白の $\beta-\gamma$ 位にBence Jones蛋白 $\boldsymbol{x}$ 型を認め, 胸水にも異型形質細胞を証 明した。 ところが血清中にはM成分を認めず，免 疫ダロブリンは全て低値であつた。一方，右大腿 骨と右肩甲骨にレントゲン写真上，打ち抜き像が 出現した。

骨髄腫の増殖形式としては，多発性骨䯣腫，孤

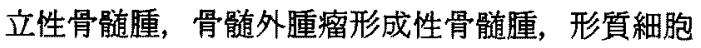
白血病，原発性骨䯣外形質細胞腫が知られてい る12). 本例は異型形質細胞が多数の腫瘤を形成 し，骨䯣穿刺，剖検時の骨䯣所見上り腫瘤形成性 形質細胞腫と診断された。剖検にて横断性等髄障 害は腯瘤の春椎管内転移による胸䯣への圧迫によ つて出現し, 脳神経症状は䯣膜癌腫症による障害 と考えた。

骨䯣腫は一般に脳神経症状を合併することはま れであると言われている.

小林ら゙は，多発性骨髄腫によりCollet-Sicard 症候群を呈した50才の女性例を報告している。 Gardner-Thorpe ${ }^{\text {s) }}$ は斜台に発生し, 左舌下神経麻 疸を呈した形質細胞腫を報告している。一方 Silverstein $5^{4)}$ によと277例の骨髄腫の中で脳神 経症状を呈したものは 3 例で，そのらちわけは第 VI脳神経障害, 第III, IV, VI脳神経障害, 第VII X XII 脳神経障害であつた。Clarke 25例中, 脳神経のうちで障害されやすい部位は第 VI，第VIII，第 V脳神経が多く，他の脳神経はまれ であると述へててい、これらの症例は骨髄腫細胞 が脳神経へ直接浸潤，あるいは周囲組織への高度 の浸潤により近隣の脳神経を巻き込んたたために脳 神経症状が生じたすのである。しかし我々の症例 では頭蓋底部に転移あるいは骨破壊は証明されな かつた。そんため腫瘍細胞の髄膜癌腫症の部分症 状として脳神経症状が起こつたものと考兄る。

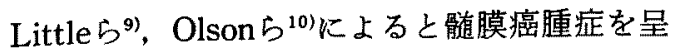

した悪性腫瘍は乳癌が最も多く，次いで肺癌，リ ンパ盾で，多発性骨髄腫は含まれていなかつた。 Lesseら ${ }^{11)}$ は癌で死亡した595例のうち86例に㗙膜 への浸潤を認め，多発性骨髄腫によるものは 5 例 であつたと述べている。

髄膜癌腫症の脳神経症状はLittleら ${ }^{9)}$ の報告で は29例中21例に認められ，その中では第VII脳神経 障害が12例と最も多く，次いで第 V脳神経障害の 8 例で，第XII脳神経障害は 4 例に認められた。 Olson ${ }^{10)}$ の報告では，50例中47例に脳神経障害 が認められ，この中ではIII，IV，VI脳神経障害が 35例で最も多い，XII脳神経障害は10例に認めら れた。しかし組織学的に脳神経へ腫場細胞の浸潤 を確認したのは10例であつた. Maldonadoら5)の 症例は，末期に左第VII脳神経症状を呈しているが, その原因については述べられていない，しかし剖 検にて頭蓋骨に腫瑒が浸潤しておらず，髄膜への 腫湯細胞の著明な浸潤から考点て髄膜癌腫症の脳 神経障害と考える。

我々の症例のように舌下神経麻㯰を主症状とし て発症した悪性腫湯は，文献上極めて少ない， Rubinstein ${ }^{12)}$ は悪性腫湯の頭蓋内転移の初発徵候 として舌下神経麻㾇を来したもの 7 例を報告して いる. その原発巣はHodgkin病 2 例, 白血病 1 例, リンパ尰 1 例, 肺癌 3 例で全例に䯣膜への董珕細 胞の浸潤を認めている，本邦では小田ら ${ }^{13)}$ の胃癌 にて舌下神経麻痁を呈した症例が報告されてお り，剖検にて髄膜癌腫症の所見が確認されている が，形質細胞腫によるるのは我々が調べ得た限り に招いて報告がない. Maldonadoら5は硬膜に形 質細胞が浸潤するものは少ないと述べている。 我々の症例も, 硬膜には肉眼的にも組織学的にも 形質細胞の浸潤は認められなかつた。

ところで本例では胸髄レべルで横断性脊檤障害 も出現した。原因は剖検所見から，腫瘤が资髄を 王迫したことによると考劣られる，その部分を切 断すると, 继状壊死物質が流九出し, 組織学的に もcysticな変化を来しており，王迫壊死に陥つて いた。 また可迫部位より上位の春髄の横断面では, 後索と脊髄小脳路が海綿状变化に陥り, 上行性変 
化が出現したものと考えられた ${ }^{14)}$. Clarke ${ }^{15)}$ は多 発性骨䯣腫の約 $20 \%$ に筒髄王迫が見られると述べ ている.荒木ら ${ }^{14)} に よ る と ， 355$ 例の脊䯣硬膜外転 移のうち，多発性脊髄腫は10例 $(2.8 \%)$ である。 本例は胸䯣への腫瘤の圧迫があり，頻度的には最 も一般的な部位への転移があつた ${ }^{14) 16)}$.

本例の原発巣は, 入院時の胸部レンドゲン写真, 胸部CTにて, 左胸腔内に球形の腫瘤が存在し, 胸 水中から異型形質細胞が証明されたこと，また骨 䯣穿刺にて骨髄腫を疑わせる所見がなかつたこ と，剖検時の骨髄標本にも悪性細胞は認められな かつたことを考古ると，胸腔内に原発し，それが 春椎管内に転移し，筹髄を圧迫，また同時に髄膜 癌腫症を引き起こしたものと考えるのが妥当であ ろら。いずれにしても我々が調べ得た限りでは, この症例のよ5に胸腔内に腫瘤を形成した形質細 胞腫は見い出せなかつた。また，形質細胞腫によ る䯣膜癌腫症や，横断性脊髄障害の症例の報告は 極めて数少ないものであつた。

結語

1）脳神経症候と横断性脊髄障害を主徵とする 腫瘤形成性形質細胞腫を報告した。

2）脳神経症候として，末梢性舌下神経障害を初 発とし，経過中に一過性の顔面神経障害，三叉神 経障害も出現した，

3）剖検所見より脳神経症候は髄膜癌腫症の部 分症状，横断性脊䯣障害は腫瘤の春髄への圧迫に よるものと考光た。

4）腫瘤形成性形質細胞腫が, 䯣膜癌腫症と横断 性春髄障害を呈した症例は，本例が最初である。

貄辟 本症例を病理組織学的儿御娭索いただきました本 学隑膓病理学の牧野剛緒先生, 小西陽一教授に梁謝いたし ます。

\section{文献}

1) Remigo PA and Klaum A: Extramedullary plasmacytoma of stomach. Cancer 27:562 1971.

2）三好和夫編：骨髄尰のすべて，初版，南江堂，東 京, 1978, p77.

3）小林逸郎，榎田雅夫：多発性骨䯣腫によりColletSicard症候群を呈した 1 剖検例. 踇床神経 21 ： 87, 1981.

4) Silverstein A and Doniger DE: Neurologic complications of myelomatosis. Arch Neurol $9: 534,1963$.

5) Maldonado JE, et al: Meningeal myeloma. Arch Intern Med 126: 660, 1970.

6) Alexander MP, et al : Solitary plasmacytoma producing cranial neuropathy. Arch Neurol 32: $777,1975$.

7) Clarke E: Cranial and intracranial myelo. mas. Brain $77: 61,1954$

8) Gardner-Thorpe $C$ : Presumed plasmacytoma of clivus producing isolated hypoglossal nerve palsy. Brit Med J 2: 405, 1970.

9) Little JR, et al: Meningeal carcinomatosis. Arch Neurol $30: 138,1974$.

10) Olson $M E$, et al: Infiltration of the leptomeninges by systemic cancer. Arch Neurol 30: 122,1974 .

11) Lesse $S$ and Netsky MG: Metastasis of neoplasms to the central nervous system and meninges. Arch Neurol Psychiatry 72: 133, 1954.

12) Rubinstein MK : Cranial mononeuropathy as the first sign of intracranial metastases. Ann Intern Med 70:49, 1969.

13）小田健一郎，他：舌下神経単麻㽻を主致とした胃 癌の頭蓋内転移。神経内科 $8: 372 ， 1978$ 。

14）荒木淑郎，岡本定昭：転移性脊髄腫煌。神経内科 $2: 221,1975$

15) Clarke E: Spinal cord involvement in multiple myelomatosis. Brain $79: 332,1956$.

16) Snyder LJ and Wilhelm SK: Multiple myeloma with spinal cord compression as the initial finding. Ann Intern Med 28 : 1169, 1948. 